\title{
Local perception of ecosystem services provided by bats and bees and their conservation in Bénin, West Africa
}

\author{
Bruno A. DJOSSA ${ }^{1,2^{*}}$, Hermann TONI ${ }^{2}$, Komivi DOSSA ${ }^{2}$, \\ Prosper AZONANHOUN ${ }^{2}$ and Brice SINSIN $^{2}$ \\ ${ }^{1}$ High School of Agronomy (ENSTA) of Kétou, University of Abomey - Calavi (UAC), Rep. of Bénin. \\ ${ }^{2}$ Laboratory of Applied Ecology, FSA, University of Abomey - Calavi (UAC), Rep. of Bénin. \\ * Corresponding author; E-mail: djossabruno@gmail.com;Tel: +(229) 95456283
}

\begin{abstract}
Indigenous perception on ecosystem services provided by honey bees and fruit bats were assessed in Bénin to find out whether the communities value these services and to appreciate if there is any chance to conserve them locally. Farmers were interviewed with questionnaire in three regions of Bénin to report their perception on bats and bees' value in nature, for human, the trend of their populations and the chance to conserve them. We reported that the communities valued more and more bees' services in nature from the Southern to the Northern of the country (3vs. 52\%). Bees were threatened according to $35 \%$ (South), $89 \%$ (Centre) and 99\% (North) of interviewees' declarations. 26-41\% persons stated there is chance to conserve them. Bats' seed dispersal was better recognized in the North (91\%) than in the Central zone (76\%) and in the South (19\%). Bats were threatened mainly by their use as bush meat (52-93\% of interviewees) and there is some chance to conserve them mainly in the South, according to percentage of respondents. Population regression was declared for these two animals everywhere. We concluded that ecosystem services provided were overall well known giving thereby some chance to promote actions to conserve them.
\end{abstract}

(C) 2012 International Formulae Group. All rights reserved.

Keywords: Bats, bees, conservation, ecosystem services, local communities

\section{INTRODUCTION}

There are numerous ecosystem services delivered in natural habitats and in agricultural landscapes. Pollination is one of these services. Pollination by animals that is a crucial service for many wild and cultivated plants is often ignored or if not considered like a gift of the nature and very little is done to improve or maintain these natural services (Priti and Sihag, 1997). However, pollination is a key ecosystem service for food security (Lundberg and Moberg, 2003; Gikungu, 2006;
Sekercioglu, 2006; Gallai et al., 2009). Pollinators are important in $35 \%$ of global crop production (Klein et al. 2007). Sixty to eighty per cent of wild plant species require animal pollinators (Kremen et al., 2007). This importance of pollinators recommends that natural resources managers take action for their conservation. But in the developing countries where the traditional and extensive agriculture occupy large portion of the populations, the threat on the natural resources in general and particularly on pollinators 
cannot be alleviated without taking into account the perception of the communities directly in contact with these organisms. In general, the majority of local people ignore the importance of these services provided, which impact greatly the yield of their crops (Munyuli, 2011). The perception of the local communities needs to be taken into account to decide relevant conservation actions to expect their agreement without which any success is possible. Getting the real perception is also important because even if they show apparent agreement of the natural resources conservation, they are usually opposite to conservation actions creating some restriction in the use of the natural resources on which they live (Silori, 2007). This demonstrates the importance of an accurate assessment of the perception of the communities on a given natural resource prior to conservation activity definition. The present study aims to assess local community's perception through the three different climatic regions of Bénin, documenting how far they value the services delivered by bats and bees in term of pollination and seed dispersal as well as the chance to conserve these organisms in the current context of continuous human pressure on natural resources. We hypothesized that the perception will differ from one region to another but also from one organism to another. These results will help natural resources managers to make decision conserving bats and bees in the rural communities, beginning by reinforcing awareness in order to guarantee the conservation of these organisms that provide key ecosystem services on which depends greatly the food security of the whole humanity.

\section{MATERIALS AND METHODS Study area}

This study has been conducted in the three major climatic regions of Bénin (Figure 1): the Guinean zone on a site between the Districts of Comé and Houéyogbé both situated in the Southwestern of the country, the Guineo-Sudanian zone, the transition zone, on a site that belong to the District of Dassa located in the central region of the country, and in the Sudanian zone in the District of Matéri situated in the extreme Northwestern of the country.

The Republic of Bénin covers a land area of $112,622 \mathrm{~km}^{2}$, of which $22.7 \%$ is legally protected (CENATEL, 1992; FAO, 2001). The population has been estimated at $8,000,000$ inhabitants with an average density of 57 inhabitants $/ \mathrm{km}^{2}$ (INSAE, 2002). The altitude varies from sea level to $400-650 \mathrm{~m}$ in the northwest, around the Atacora chain. The mean annual rainfall varies from $900 \mathrm{~mm}$ in the southwest and in the far north to 1,300 $\mathrm{mm}$ in the Southeast and Centre-west. The mean annual temperature is $26-28^{\circ} \mathrm{C}$. Southern Bénin (up to $7^{\circ} 30^{\prime} \mathrm{N}$ latitude) belongs to the Dahomey Gap, where only small islands of rainforest exist (White, 1983; Jenik, 1994). Human pressure on these forest islands has been so severe that the estimated rate of deforestation for close forest is 12 $\mathrm{km}^{2} /$ year out of a close forest cover of 470 $\mathrm{km}^{2}$ (FAO, 2001). From $7^{\circ} 30^{\prime} \mathrm{N}$ to $12^{\circ} 25^{\prime} \mathrm{N}$, the vegetation is essentially made of a patchwork of woodlands and savannas. The flora of Bénin has been estimated at 2,800 plant species (Akoègninou et al., 2006).

A close look at the soil map for Bénin reveals that ferallitic and hydromorphic soils dominate in the southern part. The crystalline basement in Central Bénin is mainly characterized by Acrisols and Lixisols (sols ferrugineux lessivés). In the Atacora Mountains in north-west Bénin, shallow soils (Lithosols, sols peu evolués lithiques) are widespread (Faure and Volkoff, 1998).

\section{Methods}

The study was carried out in communities of small farmers working on savanna dominated habitats. They practice traditional agroforestry systems characterized by subsistence agriculture. We surveyed in Bouiga, Hintchahoun, Materi, Dapoua and Poura villages in the Northern, in Tognon and 


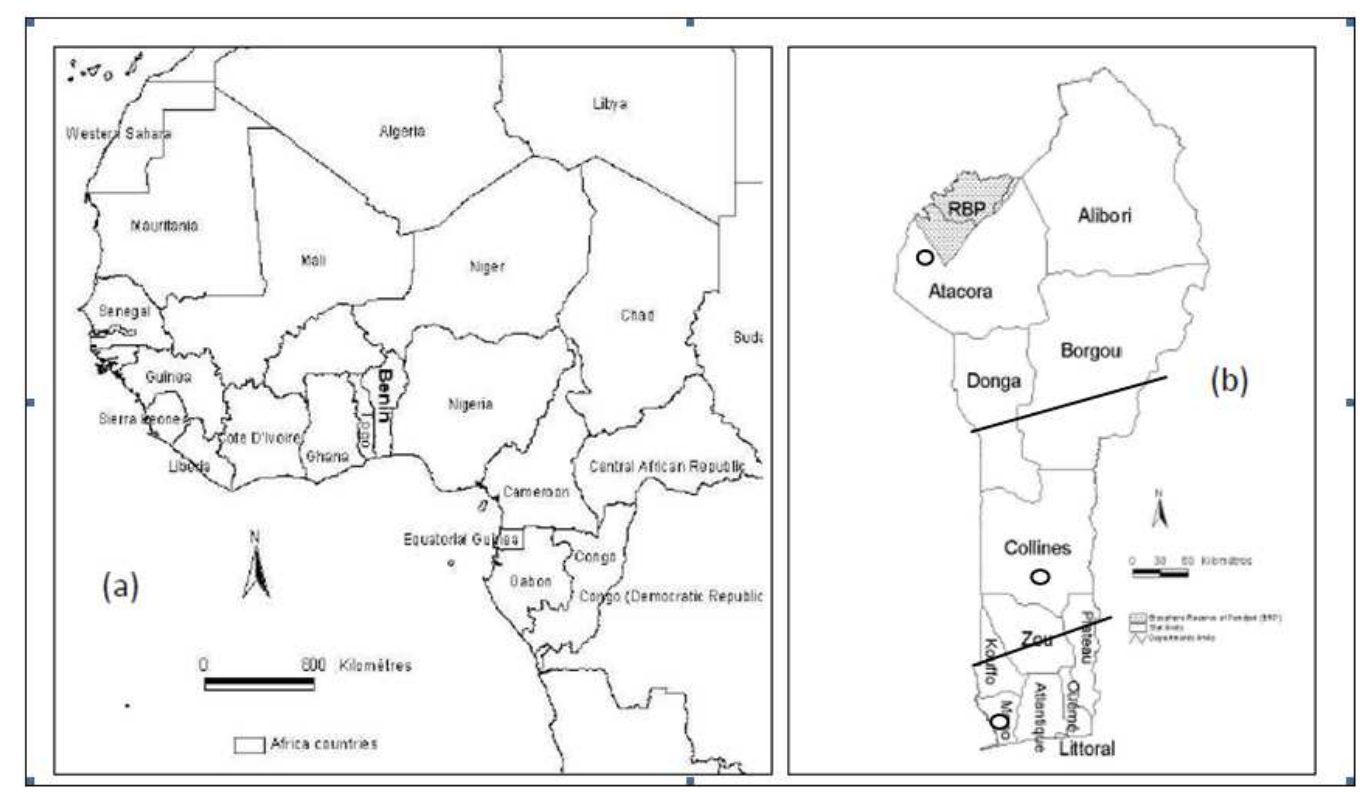

Figure 1: The situation of Bénin in Africa (a); the position of the studied districts marked with open circles and the climatic regions delineated with solid lines (b).

Bakéma villages in the Central zone and in Comé,Sessigbé,Oumako,Djanglanmè,Djakoét é, Sè, Drè, Akodéha and Houngbo villages in the Southwestern of the country. Once we gained the confidence of the villagers, semistructured interviews were conducted to document the perception of individual respondents on the importance/value of bats and bees for the nature, for humans as well as the trend of their populations and the chance to conserve them locally. In term of population fluctuation we asked the interviewees whether the populations of each animal decline or increase, the reason of this trend. We got 301 respondents from the three regions (100 in the Guinean zone, 101 in the Guineo-Sudanian zone \& 100 in the Sudanian zone). The 301 respondents were distributed as followed: 194 males and 107 females.

Responses were computed, converted in percentages and used to construct charts to represent the perception of local peoples on the different aspects put in questions.

\section{RESULTS}

Interviewees' ages ranged from 25 to 76. They were all farmers but some of them had additional activities. Their perception of bats and bees as pollinators and their conservation status were reported as follows:

\section{Local perception on bats and bees}

Local peoples interviewed declared their understandings of the role of bats as seed dispersers, bees as pollinators, the threats and the possibility to conserve them locally and the appreciation of the fluctuation of their populations in the region (Figure 2).

Bats are known as seed dispersers but not as pollinators throughout the country but awareness was much higher in the Central $(76 \%)$ and in the Northern $(91 \%)$ of the country than in the Southern (19\%) according to respondents. Fruit bats were used like bushmeat everywhere in the country but this consumption was more pronounced in the Central region (93\%). All respondents agreed that bats were threatened via their habitat 
destruction mainly and their populations were declining but declared that it was possible to conserve them even though only people of Comé-Houéyogbé region predominantly believed that (50\% vs. 9 and 12\% from Dassa and Matéri respectively). Apart from habitat destruction, bats were threatened because people considered them as vectors of diseases and kill them.

Honey bees are recognized as pollinators everywhere in the country but remarkably so few respondents declared it in the Southern region (3\% vs. $38 \%$ and $52 \%$ respectively in the Central and Northern regions). The honey production was the only one ecosystem service everybody knew for bees. The threats on bees were unanimously accepted but the awareness was much higher in Matéri (99\%) and Dassa $(89 \%)$ districts compared to what was declared in Comé and Houéyogbé districts (35\%). Bee populations diminution was also largely admitted everywhere with $69 \%, 78 \%$ and $94 \%$ of respondents declaring it in Matéri, Dassa and Comé and Houéyogbé respectively. Chance for conservation exists everywhere but was more expressed in Comé and Houéyogbé disticts (41\% vs. 26 and 30\%).

\section{Local perception on bats and bees according to gender}

The local perceptions reported on the different aspects were analyzed with regard to gender to find out any difference in perception (Figure $3 \mathrm{a}$ and $3 \mathrm{~b}$ ). Local perception of men and women were roughly similar, except for seed dispersal in Comé and Houéyogbé districts where less respondent women (7\%) were aware compared with the number of men showing awareness of the same ecosystem service $(23.6 \%)$ and for the chance to conserve bats that only men declared in Dassa district. (Figure $3 \mathrm{~b}$ ) Local perception of men and women were roughly similar for all ecosystem services, except for pollination only declared by men in Comé and Houéyogbé districts and for the chance to conserve bees that more men declared in Dassa district in contrary to respondents' proportion in Matéri district.

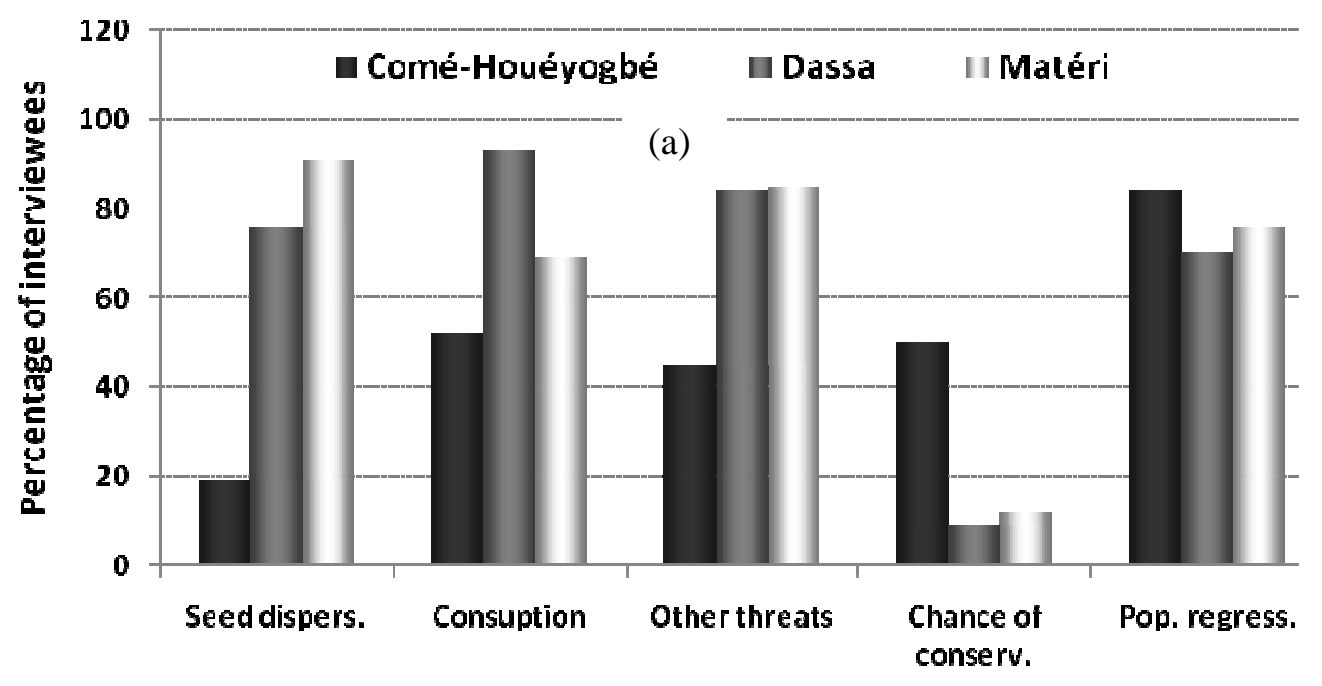

Local perception on fruit bats 


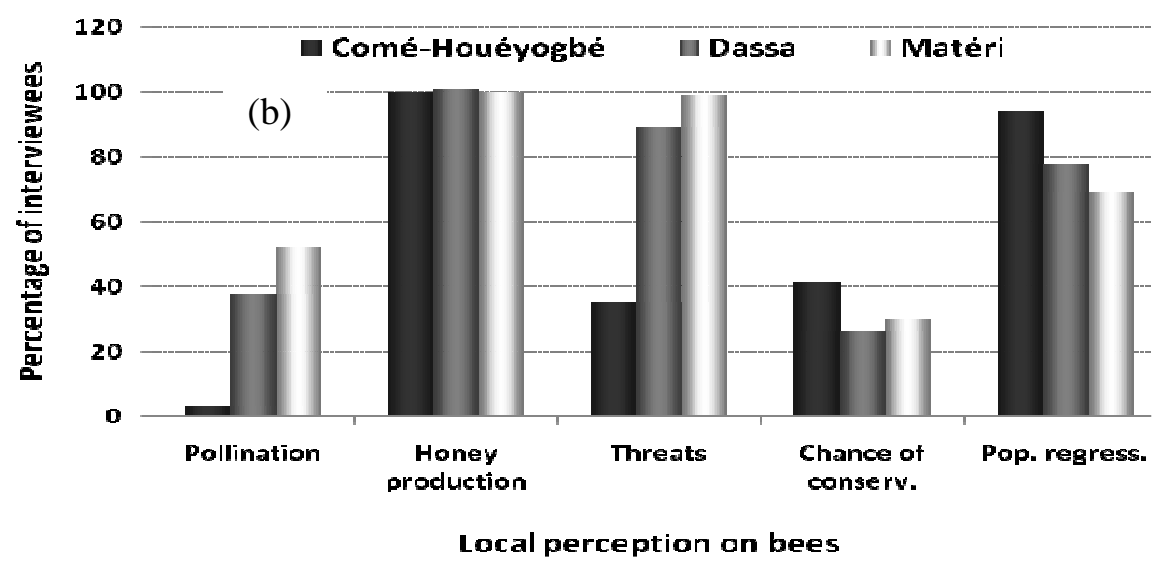

Figure 2: Local peoples' perception on ecosystem services provided by bats (a) and bees (b) and their conservation status.

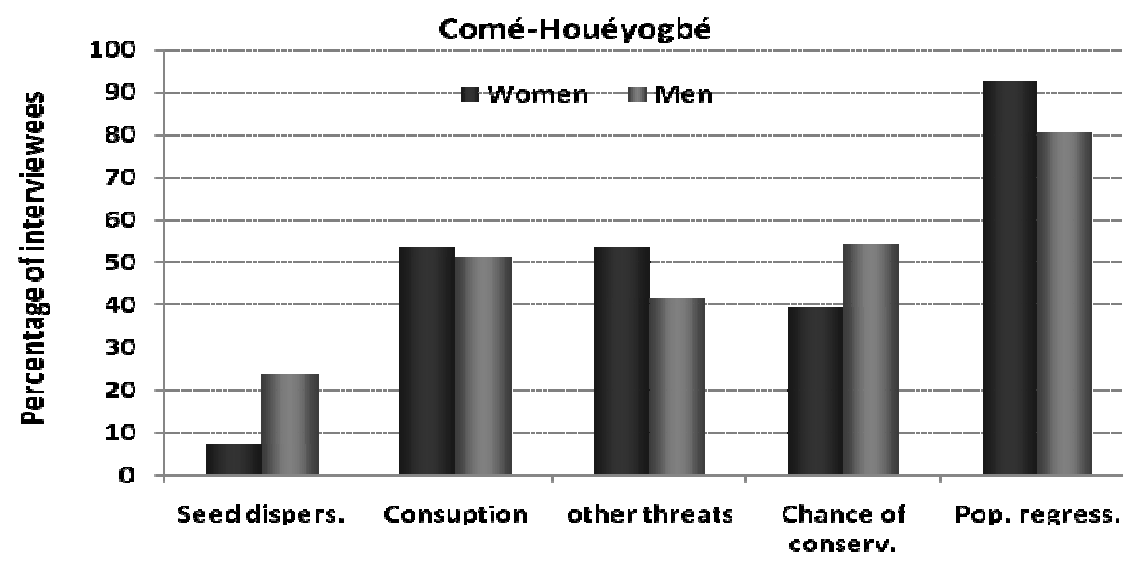

Local perception on bats

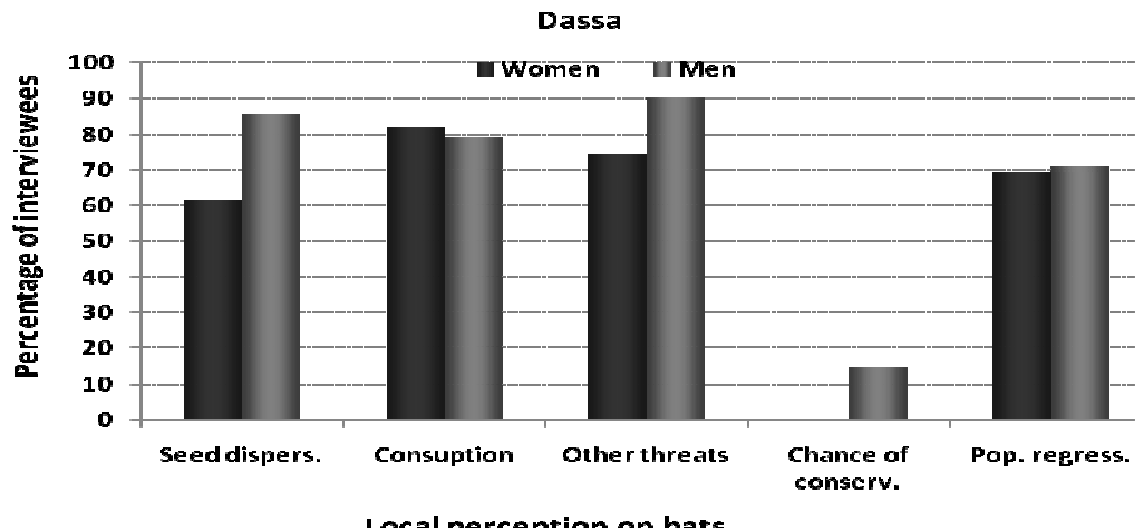




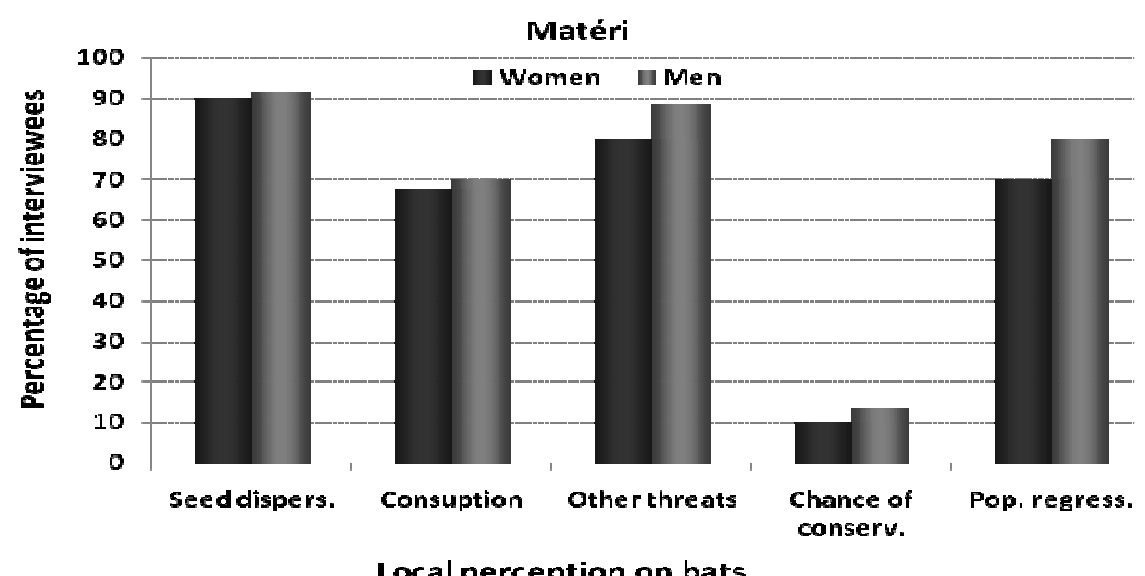

Figure 3a: Local perception on bats according to gender in Comé, Houéyogbé, Dassa and Matéri.
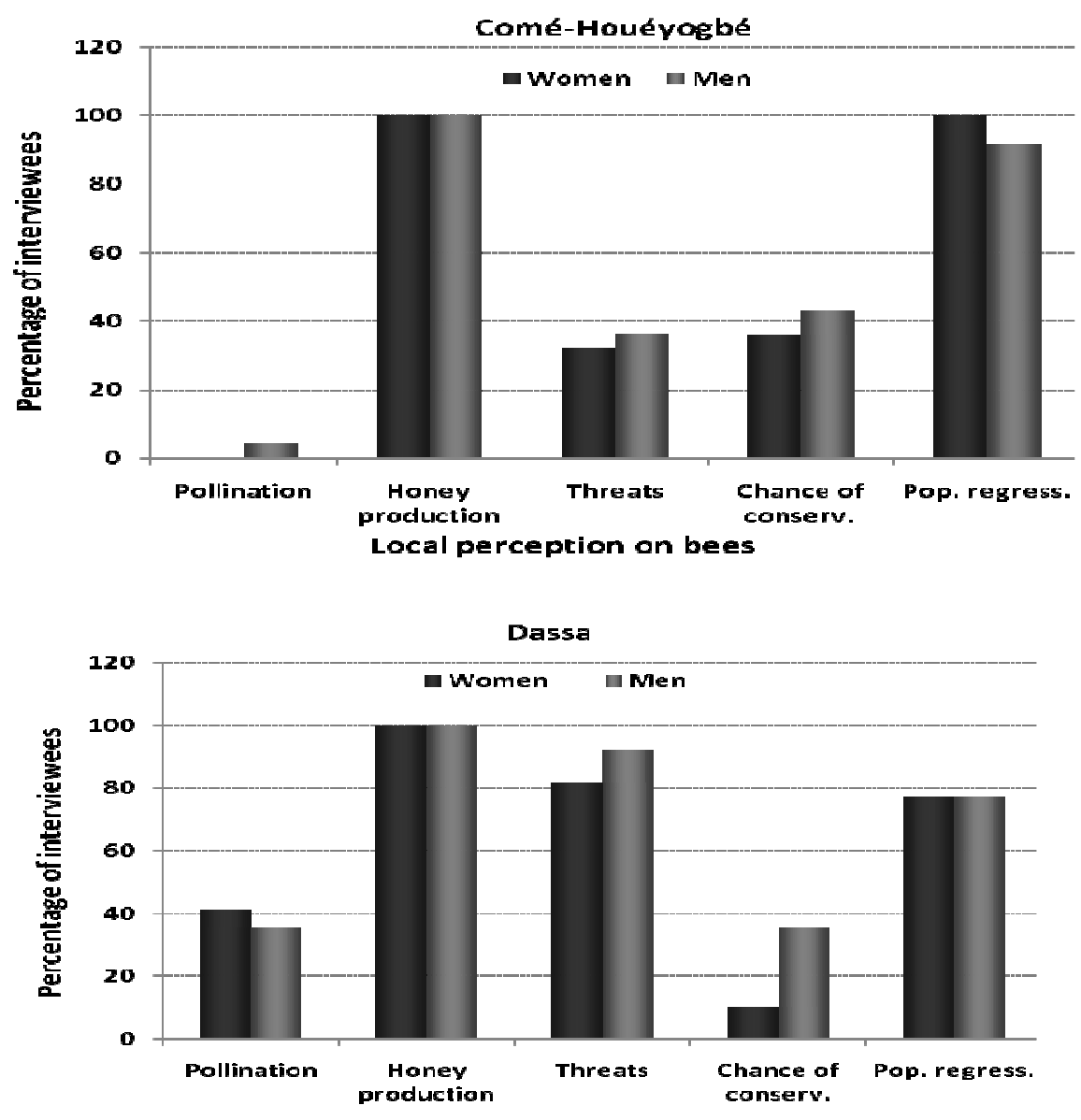

Local perception on bees 


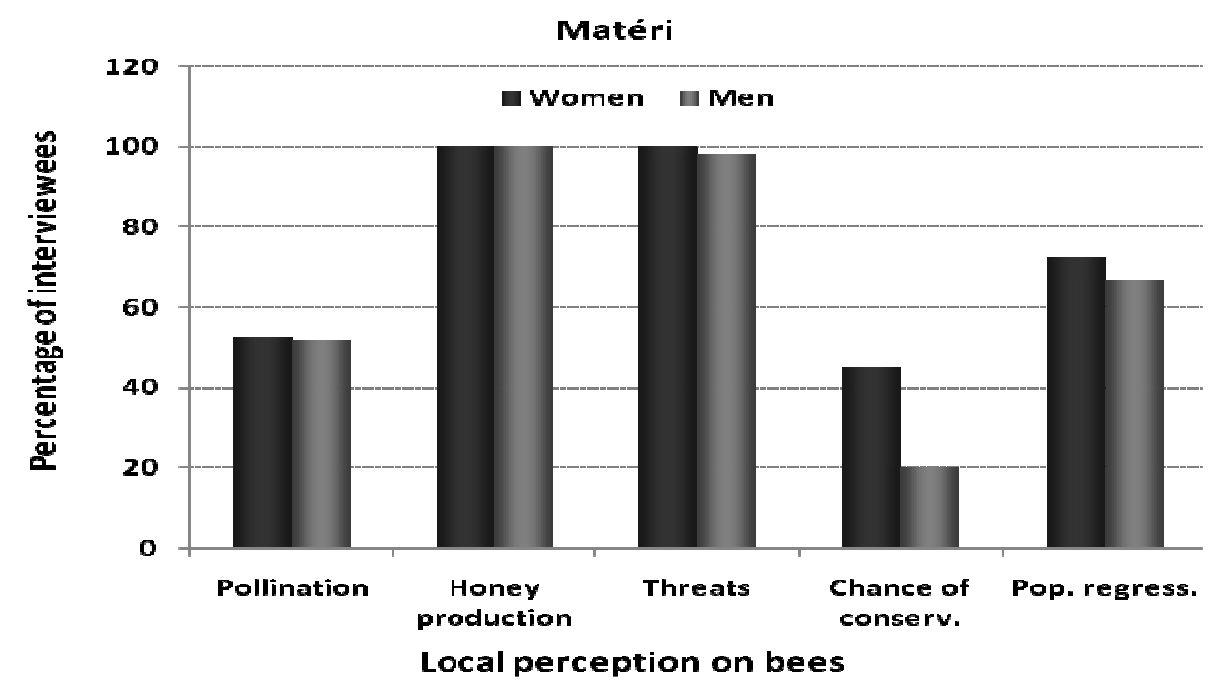

Figure 3b: Local perception on bees according to gender in Comé, Houéyogbé, Dassa and Matéri.

\section{DISCUSSION}

Conservation of natural resources in general and key ecosystem services such as pollination and seed dispersal require the participation or at least the agreement of communities living in the vicinity of the resources (Silori, 2007). It is known that poverty and conservation are a dilemma so that the awareness of the communities seems to be very important to expect any change in natural resources use approach. Due to the need to solve daily problems, rural communities usually over exploit the natural resources on which they depend complicating their own survival conditions. Although the percentage of the earth's surface devoted to protected areas has steadily increased, conservation agencies readily admit that many protected areas are protected in name only and that many suffer from widespread illegal use, which in some cases is leading to loss of biodiversity (Carey et al., 2000). The perception of the local peoples is important because when they decide themselves to conserve natural resources the impact is noticeable. Recent work has shown that communities' own conservation efforts probably equate to forested areas currently within formal protected area networks and that many communities spend more per hectare on conservation than national governments (Molnar et al., 2004). The local communities usually take advantage of traditional wisdom and religious beliefs to give sacred value to different natural resources such as trees, forests, lakes, rivers, etc. they found important to conserve. Silori (2001) reported from India that such attitudes of locals have helped to restrain the level of anthropogenic pressures in the Nanda Devi Biosphere Reserve. It appears that when locals don't perceive the necessity to conserve a given natural resource, even if they show superficial agreement, there is frequently lack of cooperation between resource users and managers and this is known to be source of conflict (Silori, 2007) that is detrimental to the conservation of the resources. Before taking into account the local persons' aspiration when deciding to conserve natural resources, it seems important to know the perception of these persons on the given resources otherwise there is a great chance to decide against their interest. Doing that may possibly create disagreement and conflict between managers and local peoples. When it comes to 
deal with non tangible services such as pollination or seed dispersal that are of key importance for food security for humanity, we think that it is relevant to check if the local peoples are aware of what they mean. Usually, they ignore what the natural resources managers want them to conserve. Munyuli (2011) conducted a survey on Uganda farmers and found that more than $90 \%$ of interviewed farmers were not aware of the role played by bees in coffee yield increase. The same author also reported that farmers were not willing to manage their lands to protect pollination services, particularly because they considered pollination service as an unsolicited "free service", or as a "public good". Taking into account this, we surveyed in different community in Bénin to report their awareness of the ecosystem services provided by honey bees and fruit bats. In an other hand, we assessed whether there is a difference of perception between males and females and reported that awareness were overall similar for almost every aspect except on the pollination by bees and seed dispersal by fruit bats on which women were less aware than men in the Southern of the country (Comé and Houéyogbé) compared with the Centre (Dassa) and the North of the country (Matéri). Comparable results were obtained with a similar study in Uganda where men and women living in the same areas showed different awareness on specific ecosystem service like the contribution of the microorganisms to soil fertility improvement (Munyuli, 2011). This demonstrates that the contribution of each component of the community needs to be handled differently to guarantee their contribution to conservation matters.

With this study, it apparent that the perception of ecosystem services provided by bees and bats varies in the different communities throughout Bénin and the gender influenced only when dealing with non tangible aspects like pollination or seed dispersal.

\section{Conclusion}

This study showed that the local communities have different awareness of the ecosystem services provided by fruit bats and honey bees and perceive their importance differently throughout the country. The perception was also weakly influenced by the gender. All this recommend that conservation activities toward these key organisms rely on the perception of each community to increase chance of success.

\section{ACKNOWLEDGEMENTS}

We are grateful to local communities for collaborating during this study, to the Volkswagen Foundation for financial support and to the reviewers for their valuable contribution to the quality of this paper.

\section{REFERENCES}

Akoègninou $\mathrm{A}$, van der Burg $\mathrm{WJ}$, van der Maesen LJG. 2006. Flore Analytique du Bénin. Backhuys Publishers: Wageningen.

Carey C, Dudley N, Stolton S. 2000. Squandering Paradise? The Importance and Vulnerability of the World's Protected Areas. WWF-World Wide Fund for Nature, Gland: Switzerland.

CENATEL 1992. Carte des aires protégées du Bénin extraite de la carte générale du Bénin au 1/600.000, IGN 1992, Cotonou, Bénin.

FAO 2001. Global Forest Resource Assessment 2000: Main Report. FAO: Rome.

Faure P, Volkoff B. 1998. Some factors affecting regional differen- tiation of the soils in the Republic of Benin (West Africa). Catena., 32: 281-306.

Gallai N, Salles J-M, Settele J, Vaissière BE. 2009. Economic valuation of the vulnerability of world agriculture confronted with pollinator decline. Ecological Economics, 68: 810-821.

Gikungu MW. 2006. Bee diversity and some aspects of their ecological interactions with plants in a successional tropical 
community. Ph.D. Dissertation, University of Bonn, p 201.

INSAE-RGPH 2002. Recensement général de la population et de l'habitat. Résultats provisoires: Cotonou, Bénin.

Jenik J. 1994. The Dahomey Gap: An important issue in African phytogeography. Mém. Soc. Biogéogr., (3èm série) IV, 125-133.

Kremen C, Williams NM, Aizen MA, Gemmill-Herren B, LeBuhn G, Minckley R, Packer L, Potts SG, Roulston T, Steffan-Dewenter I, Vazquez DP, Winfree R, Adams L, Crone EE, Greenleaf SS, Keitt TH, Klein A-M, Regetz J, Ricketts TH. 2007. Pollination and other ecosystem services produced by mobile organisms: a conceptual framework for the effects of land-use change. Ecology Letters, 10: 299-314.

Lundberg J, Moberg F. 2003. Mobile link organisms and ecosystem functioning: implications for ecosystem resilience and management. Ecosystems, 6: 87-98.

Molnar A, Scherr SJ, Khare A. 2004. Who Conserves the World's Forests? Community-driven Strategies to Protect Forests and Preserve Rights. Forest
Trends and Ecoagriculture Partners: Washington, DC.

Munyuli T. 2011. Farmers' perceptions of pollinators' importance in coffee production in Uganda. Agricultural Sciences, 2(3): 318-333.

Priti, Sihag RC. 1997. Diversity, visitation, frequency, foraging behaviour and pollinating efficiency of insect pollinators visiting cauliflower (Brassica oleracea L. var. botrytis cv. Hazipur Local) blossoms. Indian Bee Journal, 59: 230-237.

Sekercioglu CH. 2006. Avian ecosystem services. Trends Ecol. Evol., 21: 464-471.

Silori CS. 2001. Status and distribution of anthropogenic pressure in the buffer zone of Nanda Devi Biosphere Reserve. Biodivers. Conserv., 10: 1113-1130.

Silori CS. 2007. Perception of local people towards conservation of forest resources in Nanda Devi Biosphere Reserve, northwestern Himalaya, India Biodivers. Conserv., 16: 211-222.

White F. 1983. The vegetation of Africa, a descriptive memoir to accompany the UNESCO/AETFAT/UNSO. UNESCO, Natural Resources Research, 20: 1-356. 